Vol. 1 No. 1, Feb 2021, hlm. 111 - 120

DOI: https://doi.org/10.33330/.v1i1.1057

Available online at https://jurnal.stmikroyal.ac.id/index.php/jutsi

\title{
PENERAPAN K-MEDOIDS CLUSTERING PADA EKSPOR BUAH-BUAHAN MENURUT NEGARA TUJUAN
}

\author{
Aris Saputri ${ }^{1}$, Hidayatullah $^{2 *}$, Ari Dermawan ${ }^{3}$ \\ ${ }^{1}$ Mahasiswa Prodi Sistem Informasi, STMIK Royal \\ ${ }^{2}$ Prodi Sistem Komputer, STMIK Royal \\ ${ }^{3}$ Prodi Manajemen Informatika, STMIK Royal \\ *email : dayatscorpio2@gmail.com
}

\begin{abstract}
Abstrack:The aim of the study is to group fruit exports according to the country of destination. The research data used came from the Indonesian Central Statistics Agency with the url https://www.bps.go.id/ for the category of fruit exports by destination country. The computer science technique used is to utilize K-Medoids clustering data lamination. The results of the study are expected to provide information to the government about the mapping results in the form of clusters of the destination countries for the number of fruit exports. This needs to be done to review the process of fruit exports to destination countries, bearing in mind the results of the export of these fruits have the potential to improve the Indonesian economy.
\end{abstract}

Keywords:Data mining, Klastering, K-Medoids, Fruit Export, Destination Country.

\begin{abstract}
Abstrak:Tujuan dari penelitian adalah untuk mengelompok kan ekspor buah-buahan menurut negara tujuan. Data penelitian yang digunakan berasal dari Badan Pusat Statistik Indonesia dengan kategori ekspor buah-buahan menurut negara tujuan. Teknik ilmu komputer yang digunakan adalah dengan memanfaat kan data mining klastering K-Medoids. Hasil penelitian diharapkan dapat memberikan informasi kepada pemerintah tentang hasil pemetaan berupa cluster terhadap Negara tujuan untuk jumlah ekspor buah-buahan. Hal ini perlu dilakukan untuk meninjau ulang proses ekspor buah buah kenegara tujuan mengingat hasil ekspor buah-buah tersebut berpotensi untuk meningkatkan perekonomian Indonesia.
\end{abstract}

Kata Kunci:Data mining, Klastering, K-Medoids, Ekspor Buah, Negara Tujuan

\section{PENDAHULUAN}

Ekspor merupakan mengirim barang dari suatu Negara ke negara lainnya dengan tujuan untuk mendapatkan keuntungan. Memperkenalkan produk lokal ke negara lain dan meningkatkan perekonomian Negara merupakan keuntungan dalam kegiatan ekspor [1]. Salah satu kegiatan ekspor yang memberikan keuntungan bagi, Dimana suatu Negara 
Vol. 1 No. 1, Feb 2021, hlm. 111 - 120

DOI: https://doi.org/10.33330/.v1i1.1057

Available online at https://jurnal.stmikroyal.ac.id/index.php/jutsi

memiliki asupan kebutuhan tersendiri terhadap buah-buahan lokal. Di Indonesia, komoditas hortikultura khususnya buah-buahan memiliki potensi besar untuk menambah pundi-pundi devisa negara. Berdasarkan data Badan Pusat Statistik (BPS), ekspor buah pada periode Januari - Desember 2018 naik signifikan hingga mencapai 115,58 persen jika dibanding dengan tahun 2017. Jenis buah yang banyak diekspor antara lain nanas, pisang, dan manggis.

Saat ini Indonesia merupakan peringkat ke-5 dunia sebagai Negara produsen manggis, setelah India, China, Kenya, dan Thailand. Tujuan ekspor nya telah menembus banyak Negara seperti China, Hongkong, Thailand, Vietnam, Singapura, Malaysia, Arab Saudi, Kuwait, Oman, Qatar, Amerika, Australia dan beberapa negara Asean lainnya. Berdasarkan hal tersebut ekspor buah-buah ke Negara tujuan menjadi hal yang sangat penting karena berpotensi untuk meningkatkan perekonomian Indonesia. Pemetaan terhadap Negara tujuan dengan menggunakan teknik ilmu komputer adalah hal yang dapat dilakukan untuk melihat pengelompokan pada ekspor buah-buahan menurut Negara tujuan. Banyak cabang ilmu komputer yang dapat menyelesaikan permasalah tersebut. Diantaranya adalah data mining [2].

Penelitian ini menggunakan teknik analisa clustering. Ada beberapa penelitian yang menggunakan kelebihan dari $K$-Medoids dalam memecahkan permasalah seperti yang dilakukan dengan judul Implementasi Metode $K$-Medoids Clustering untuk pengelompokan data potensi kebakaran hutan/lahan berdasarkan persebaran titik panas (Hotspot) [3]. Pada penelitian ini data mining $K$-Medoids dapat diterapkan pada pengelompokan data potensi kebakaran hutan/lahan berdasarkan persebaran titik panas (Hotspot) dengan hasil-hasil clustering menunjukkan bahwa dengan penggunaan 2 cluster menghasilkan kelompok data dengan potensi yang dimiliki yaitu cluster 1 termasuk dalam potensi tinggi dengan hasil rata-rata brightness sebesar 344.47 derajat kelvin dengan rata-rata confidence 87.08 persen dan cluster 2 masuk dalam potensi sedang dengan hasil rata-rata brightness sebesar 318.80 derajat kelvin dengan rata-rata confidence sebesar 58,73 persen.

Peneliti K-Medoids berikutnya dilakukan dengan judul Optimalisasi K-Medoids dalam pengklasteran mahasiswa pelamar beasiswa dengan Cubic Clustering Criterion. Pada penelitian ini K-Medoids dapat diterapkan dengan memaksimalkan Cubic Clustering Criterion pada dalam pengklasteran mahasiswa pelamar beasiswa [4]. Hasil penelitian menunjukkan bahwa dataset modifikasi keseluruhan mempunyai keseragaman yang baik. Hal ini dikarenakan semua nilai pada setiap atribut memiliki nilai yang hampir sama. Berdasarkan kelebihan tersebut, solusi yang diberikan pada penelitian ini menggunakan metode $K$-Medoids yang diharapkan hasil penelitian dapat memberikan informasi kepada pemerintah tentang hasil pemetaan berupa cluster terhadap Negara tujuan untuk jumlah ekspor buah-buahan.

\section{METODE}

Metode penelitian yang dipergunakan dalam penelitian ini yaitu metode kualitatif, karena metode ini bersifat deskriptif dan cenderung analisis yang berupa kata-kata tertulis 
Vol. 1 No. 1, Feb 2021, hlm. 111 - 120

DOI: https://doi.org/10.33330/.v1i1.1057

Available online at https://jurnal.stmikroyal.ac.id/index.php/jutsi

atau lisan dari perilaku yang diamati. Metode kualitatif lebih sering menggunakan proses mendalam yaitu dengan mempelajari masalah secara kasus perkasus karena metode kualitatif yakin bahwa suatu masalah satu akan berbeda dengan masalah lainnya [5].

\section{HASIL DAN PEMBAHASAN}

\section{Halaman Login}

Halaman login adalah halaman untuk hak atau batasan terhadap user untuk masuk kedalam pengolahan sistem. Username dan password yang sah dimiliki pengguna untuk berhak masuk ke dalam system melalui halaman login. Gambar di bawah ini adalah tampilan halaman login. Bagian dari menu awal pada tools Rapidminer seperti tampilan awal dari Rapidminer dan akan dimulai dengan menu New Process.

\section{Input Sistem}

Sistem menjelaskan cara memasuk kan data baru yang akan dieksekusi lebih lanjut, pada hal ini data yang akan di eksekusi berupa data Excel. Data yang diproses sebagai input diolah menggunakan operator read excel yang tentunya data dipersiap kan terlebih dahulu. Data disimpan dengan file ekspr buahan.xls dengan atribut negara asal, jumlah ekspor (netto) dan nila iFree On Board (US\$) tahun 2015-2018 (11 record). Lakukan Drag dan Drop pada operator Read Excel sehingga seperti gambar berikut.

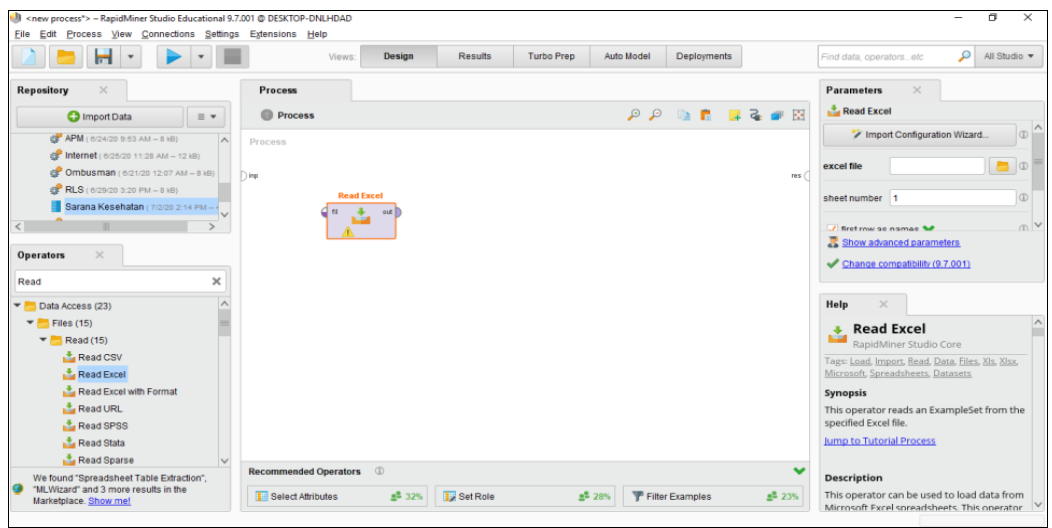

Gambar 1. Drag dan Drop pada operator Read Excel

Setelah Drag dan Drop pada operator Read Excel, lakukan double klik untuk memasukkan data excel (ekspor buah-buahan.xls) yang telah disediakan sebelumnya. Ikuti proses step by step. Sebenarnya RapidMiner akanmemberikan tipe data yang tepat secara otomatis. Namun, jika tipe data yang diberikan RapidMiner tidak cocok, maka tipe datadapatdiubah sesuai dengan kebutuhan.Sebelum proses input selesai, pada format column yang harus diperhatikan adalah status atribut negara diubah menjad id karena proses pemetaan berupa klaster berdasarkan negara tujuan. Setelah selesai klik finish. 
Vol. 1 No. 1, Feb 2021, hlm. $111-120$

DOI: https://doi.org/10.33330/.v1i1.1057

Available online at https://jurnal.stmikroyal.ac.id/index.php/jutsi

Untuk memastikan data yang di input benar, hubungkan output pada database ke result seperti Gambar berikut. Lalu klik ikon Play seperti yang ditunjukkan pada gambar 2.

\begin{tabular}{|c|c|c|c|c|c|c|c|c|c|c|}
\hline \multirow{2}{*}{ Data } & \multirow{2}{*}{$\begin{array}{l}\text { Openin } \\
\text { Row No. }\end{array}$} & \multirow{2}{*}{$\begin{array}{l}\text { Turbo Prep } \\
\text { NegaraAsal } \\
\end{array}$} & \multicolumn{5}{|c|}{ Aill Auto Hodel } & \multicolumn{2}{|c|}{ Filter (11/ 11 examples): } & r \\
\hline & & & $\mathrm{x} 1$ & $x_{2}$ & $x_{3}$ & $x 4$ & $x_{5}$ & $x_{6}$ & $\mathrm{X} 7$ & $X_{8}$ \\
\hline \multirow{4}{*}{$\underset{\text { Statistics }}{\bar{E}}$} & 1 & Tiongkok & 217120.100 & 279289.600 & 215835.900 & 341863.900 & 339657.500 & 564379 & 397717.300 & 741351.400 \\
\hline & 2 & AmerikaSerikat & 42385.400 & 106702.800 & 59091.100 & 141670.300 & 46055.600 & 116226.600 & 38045.300 & 110523 \\
\hline & 3 & Thailand & 52781.700 & 72664.900 & 33995.100 & 93035.500 & 100901.100 & 157770.200 & 61576.800 & 112881.900 \\
\hline & 4 & Australia & 29965.800 & 66297.500 & 60375 & 85314.600 & 27053.100 & 89212.600 & 27166.300 & 100704.300 \\
\hline \multirow{3}{*}{$\underset{\substack{1 \\
\text { Visualizations }}}{\bar{c}}$} & 5 & Pakistan & 20271 & 23025.700 & 12784.700 & 29192.500 & 46907.500 & 59007.800 & 48859.300 & 69059.100 \\
\hline & 6 & Peru & 5189.300 & 20565.400 & 7433.700 & 29166.300 & 9172.600 & 36689.500 & 2730.100 & 11272.900 \\
\hline & 7 & SelandiaBaru & 6614.500 & 15902300 & 17309 & 20441.100 & 9366.600 & 24073.200 & 6589.500 & 19880.600 \\
\hline \multirow{4}{*}{ 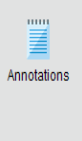 } & 8 & Vietnam & 10365.200 & 12733.300 & 14130.200 & 19172.900 & 4846.500 & 12077 & 1560 & 7050.800 \\
\hline & 9 & AfrikaSelatan & 9721.900 & 11494.600 & 10194.300 & 16428 & 14895.100 & 25168 & 11711.500 & 22550.200 \\
\hline & 10 & Mesir & 12010.700 & 10951.600 & 11891.300 & 10703.100 & 20269.500 & 21565.700 & 23975.400 & 27461.600 \\
\hline & 11 & Lainnya & 28578.500 & 46745.300 & 37488.300 & 61149 & 44685.600 & 85397.700 & 947610.900 & 826419.400 \\
\hline
\end{tabular}

Gambar 2. Isi data penelitian pada Rapid Miner

Pada gambar 2 dapat dijelaskan bahwa isi data penelitian dapat kita lihat dengan cara menghubungkan output repositori ke result seperti yang ditunjukkan pada gambar 5.8 Untuk melihat data lengkap atribut yang digunakan, klik icon statistic sehingga tampil data lengkap atribut mulai dari tipe data, missing, statistics, filter, value seperti yang ditunjukkan pada gambar berikut:

Untuk membuat $k$-medoids dengan menggunakan RapidMiner, maka dibutuhkan operator k-medoids yang terdapat pada View Operators. Untuk menggunakannya pilih Modelling pada View Operator, lalu pilih Segmentation, lalu pilih k-medoids.

Setelah menemukan operator k-medoids, seret (drag) operator tersebut lalu letakkan (drop) ke dalam viewProcess. Kemudian susun posisinya disamping operator Read Excel, seperti yang tampak pada gambar 3.

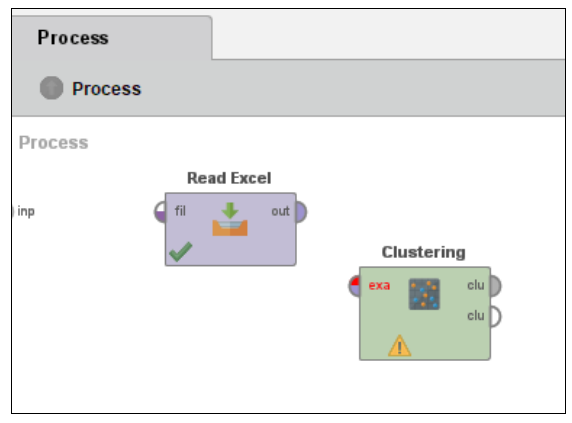

Gambar 3. Posisi Operator K-Medoids

Selanjutnya, hubungkan operator Read Excel dengan operator k-medoids dengan menarik garis dari Read Excel ke operator k-medoids. Dalam hal ini penulis menggunakan operator cluster distance performance dengan cara melakukan drag dan drop kedalam view Process. Kemudian menarik garis lagi dari operator $k$-medoids ke cluster distance 
Vol. 1 No. 1, Feb 2021, hlm. $111-120$

DOI: https://doi.org/10.33330/.v1i1.1057

Available online at https://jurnal.stmikroyal.ac.id/index.php/jutsi

performance dan dari cluster distance performance menarik garis ke result di sisi kanan, seperti yang tampak pada Gambar berikut.

Operator $k$-medoids berguna untuk melakukan pengelompokan bersama objek yang mirip satu sama lain dan berbeda dengan objek milik klaster lain. Sementara operator cluster distance performanceberguna untuk evaluasi kinerja metode pengelompokan berbasis centroid. Operator ini memberikan daftar nilai kriteria kinerja berdasarkan centroid klaster.

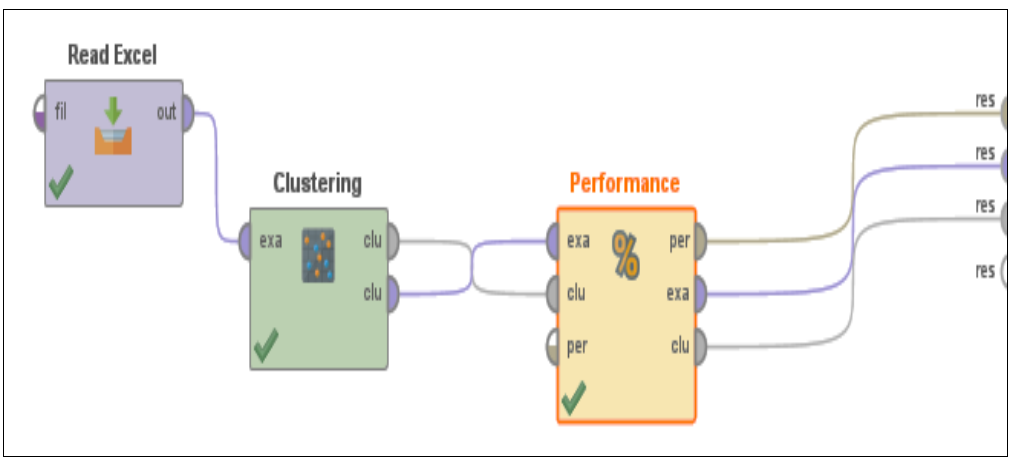

Gambar 4. Menghubungkan tabel ekspor buahan.xls dengan k-medoids dan cluster distance performance

Langkah selanjutnya adalah mengatur parameter sesuai dengan kebutuhan. Setelah menghubungkan operator Read Excel dengan operator $k$-medoids, atur parameter $k$-medoids seperti pada gambar berikut.

\section{Proses Sistem}

Pada tahap ini dijelaskan tahapan proses penggunaan $k$-medoids di dalam RapidMiner. Seperti yang dijelaskan pada gambar 4, operator $k$-medoids tidak langsung dihubungkan ke results. Melainkan dihubungkan ke operator cluster distance performance yang berfungsi untuk mengevaluasi kinerja metode pengelompokan berbasis centroid. Operator ini memberikan daftar nilai kriteria kinerja berdasarkan centroid cluster. Parameter yang digunakan adalah Davies Bouldin Index (DBI).DBI sebagai acuan pengelompokan klaster terbaik dengan melihat nilai minimal dari nilai k yang diberikan.

\section{Output Sistem}

Setelah parameter diatur, klik ikon Run pada toolbar. Tunggu beberapa saat, compute rmembutuhkan waktu untuk menyelesaikan perhitungan seperti yang ditunjukkan pada gambar 5 . 
Vol. 1 No. 1, Feb 2021, hlm. $111-120$

DOI: https://doi.org/10.33330/.v1i1.1057

Available online at https://jurnal.stmikroyal.ac.id/index.php/jutsi

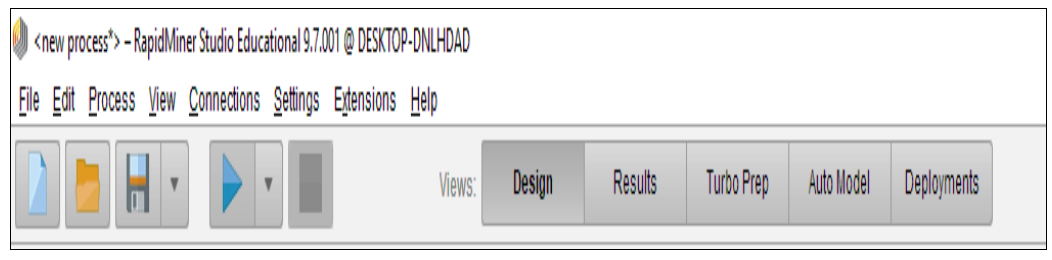

Gambar 5. Ikon Run

Setelah beberapa detik maka RapidMiner akan menampil kan hasil keputusan pada view Result. Hasil yang ditampil kan RapidMiner dapat dipilih sesuai dengan kebutuhan. Pada peneltian ini diperoleh hasil Cluster Model, Exampleset Dan Performancevector seperti yang ditunjuk kan pada gambar berikut:

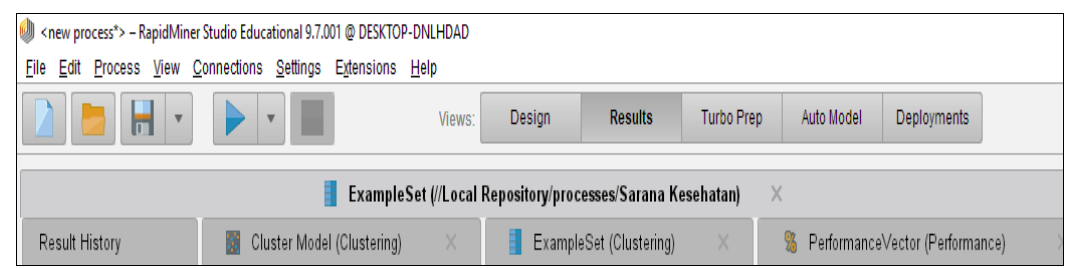

Gambar 6. Tampilan pilihan hasil dengan RapidMiner

Pada tab cluster model (clustering) dapat ditampilkan beberapa informasi seperti description, folder view, graph, centroid table dan plot. Berikut penjelasan gambar dari masing masing informasi yang ditampilkan oleh RapidMiner.

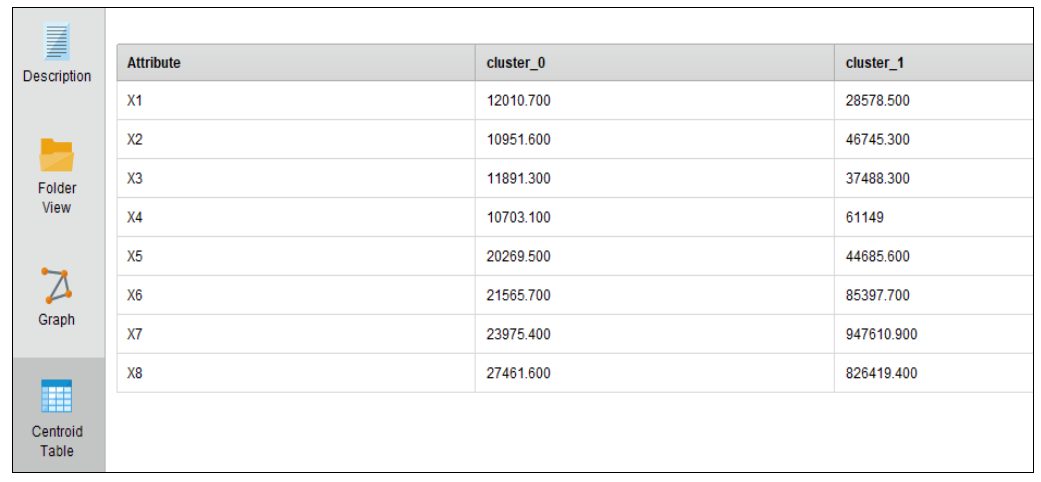

Gambar 7. Hasil centroid akhir

Pada gambar 7. adalah hasil centroid akhir dari perhitungan $k$-medoids menggunakan software RapidMiner. Hasil centoid akhir ini sama dengan hasil dari perhitungan manual. Pada tab exampleset (clustering)dapat ditampilkan beberapa informasi seperti data, statistics dan visualizations. Berikut penjelasan gambar dari masing masing informasi yang ditampilkan oleh RapidMiner. 
Vol. 1 No. 1, Feb 2021, hlm. $111-120$

DOI: https://doi.org/10.33330/.v1i1.1057

Available online at https://jurnal.stmikroyal.ac.id/index.php/jutsi

\begin{tabular}{|c|c|c|c|c|c|c|c|c|c|c|}
\hline Row No. & NegaraAsal & label & $\mathrm{x}_{1}$ & $x_{2}$ & $x_{3}$ & $x_{4}$ & $x_{5}$ & $x_{6}$ & $x 7$ & $\mathrm{x} 8$ \\
\hline 1 & Tiongkok & custer_1 & 217120.100 & 279289600 & 215835.900 & 341863.900 & 339657.500 & 564379 & 397717.300 & 741351.400 \\
\hline 2 & AmerikaSerikat & cluster_0 & 42385.400 & 106702800 & 59091.100 & 141670.300 & 46055.600 & 116226.600 & 38045.300 & 110523 \\
\hline 3 & Thailand & custe__o & 52781.700 & 72664.900 & 33995.100 & 93035.500 & 100901.100 & 157770.200 & 61576.800 & 112881.900 \\
\hline 4 & Australia & cluster_o & 29965.800 & 66297.500 & 60375 & 85314.600 & 27053.100 & 89212.600 & 27166.300 & 100704.300 \\
\hline 5 & Pakistan & cluster_0 & 20271 & 23025.700 & 12784.700 & 29192.500 & 46907.500 & 59007.800 & 48859.300 & 69059.100 \\
\hline 6 & Peru & cluste__0 & 5189.300 & 20565.400 & 7433.700 & 29166.300 & 9172.600 & 36689.500 & 2730.100 & 11272.900 \\
\hline 7 & SelandiaBaru & cluster_o & 6614.500 & 15902.300 & 17309 & 20441.100 & 9366.600 & 24073.200 & 6589.500 & 19880.600 \\
\hline 8 & Vietnam & cluster_0 & 10365.200 & 12733.300 & 14130.200 & 19172.900 & 4846.500 & 12077 & 1560 & 7050.800 \\
\hline 9 & Afrikaselatan & ciuster_0 & 9721.900 & 11494.600 & 10194.300 & 16428 & 14895.100 & 25168 & 11711.500 & 22550.200 \\
\hline 10 & Mesir & cluster_o & 12010.700 & 10951.600 & 11891.300 & 10703.100 & 20269.500 & 21565.700 & 23975.400 & 27461.600 \\
\hline 11 & Lainnya & cluster_1 & 28578.500 & 46745.300 & 37488.300 & 61149 & 44685.600 & 85397.700 & 947610.900 & 826419.400 \\
\hline
\end{tabular}

Gambar 8. Hasil lengkap klaster dengan RapidMiner

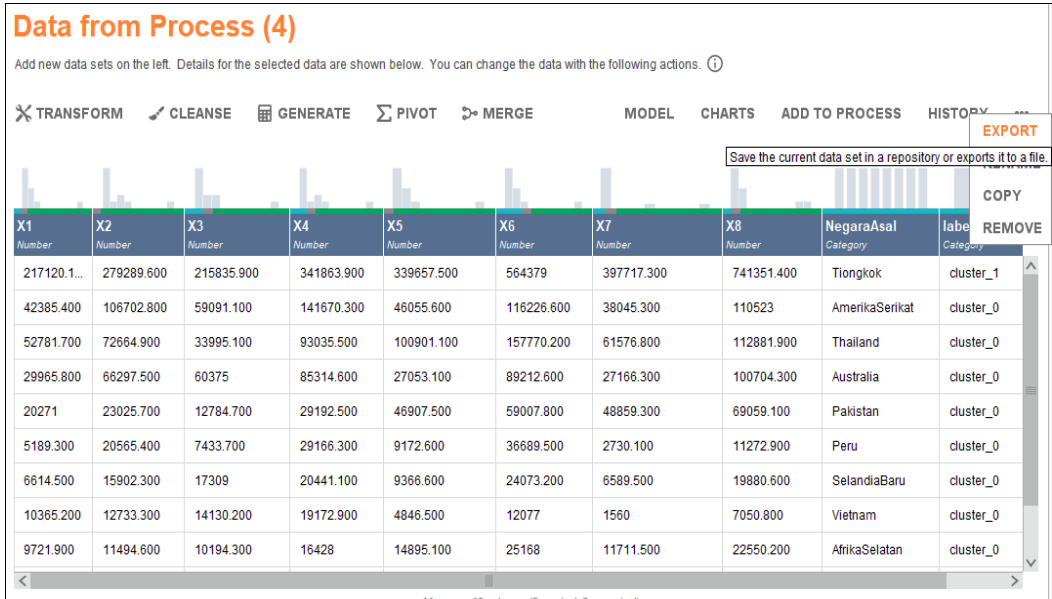

Gambar 9. Proses export hasil klaster dengan RapidMiner ke Excel

Hasil pengelompokan dengan $k$-medoids dapat dilakukan dengan menggunakan RapidMiner. Hasil dari data pengelompokan dapat di export ke Microsoft Excel seperti yang ditunjukkan pada tabel berikut ini.

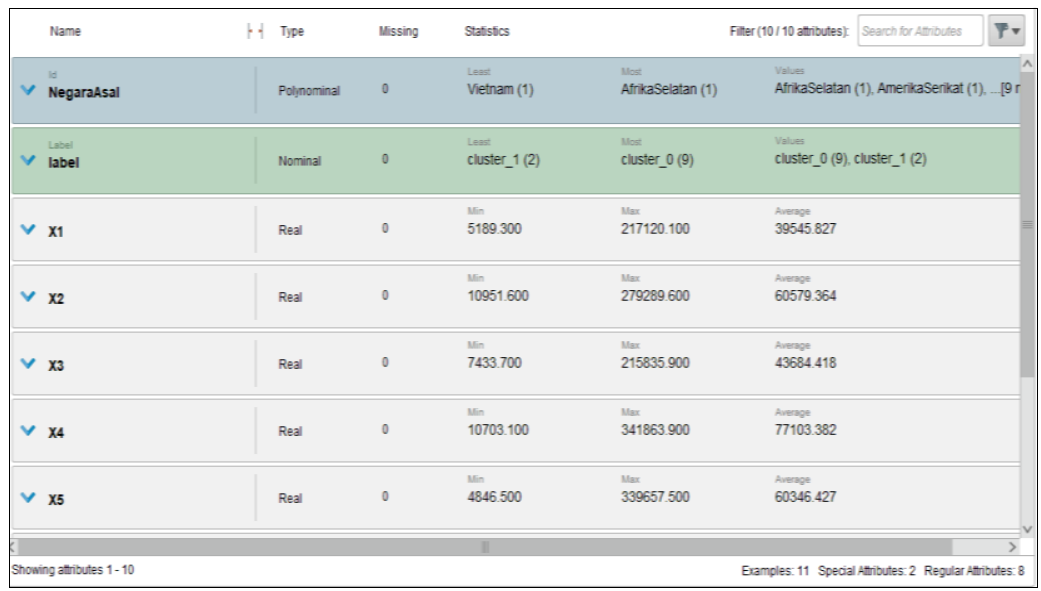

Gambar 10. Detail dari atribut yang digunakan 
Vol. 1 No. 1, Feb 2021, hlm. $111-120$

DOI: https://doi.org/10.33330/.v1i1.1057

Available online at https://jurnal.stmikroyal.ac.id/index.php/jutsi

Pada gambar 10 dijelaskan detail dari atribut yang digunakan mulai dari nama, type data, missing, statistics, batasan dari type data yang digunakan, nilai minimum dan maksimum dari record data. Untuk melihat detail data cukup dengan klik salah satu atribut.

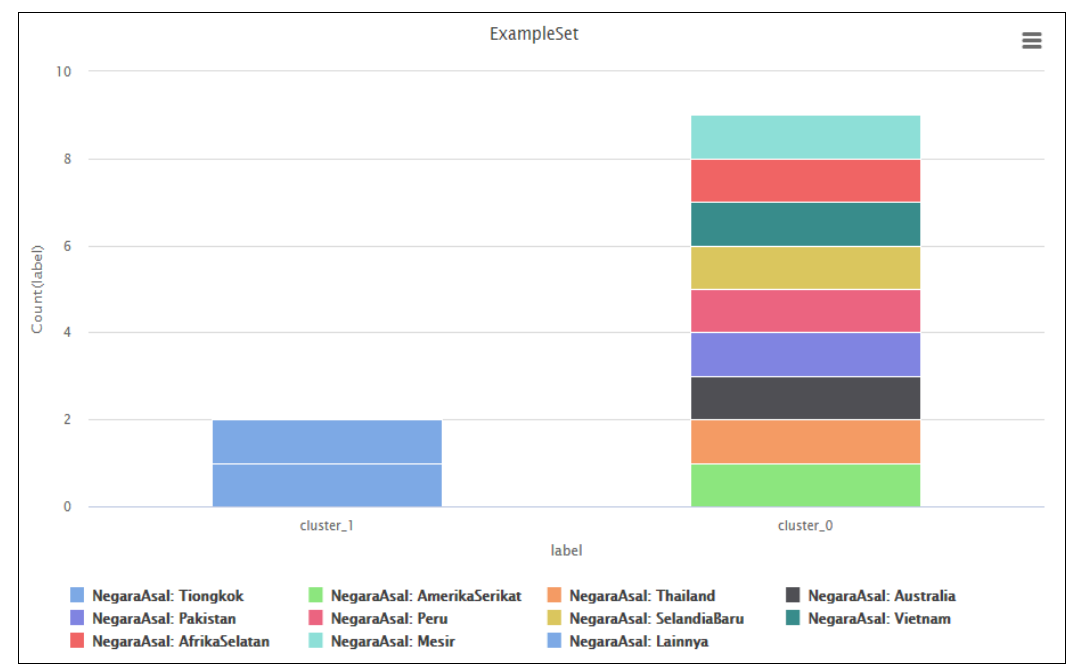

Gambar 11. Visualisasi grafik dengan Bar

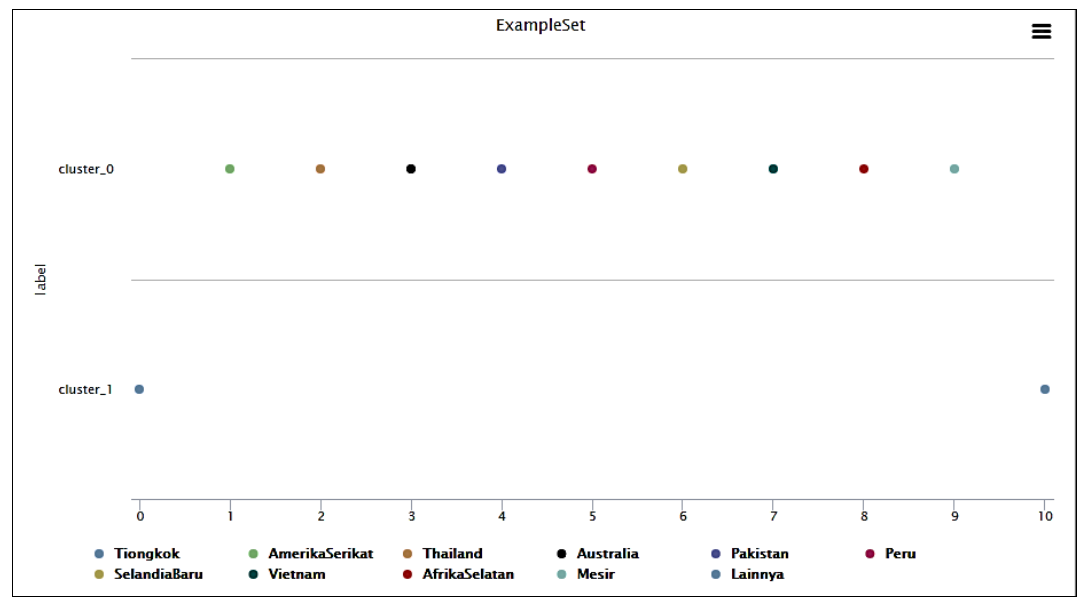

Gambar 12.Visualisasi grafik dengan scatter

Gambar 11 dan 12 merupakan pengelompokan ekspor buah-buahan menurut negara tujuan yang terdiri dari 2 klaster yakni klaster tinggi $(\mathrm{C} 1=$ cluster_1), dan klaster rendah $(\mathrm{C} 1=$ cluster_0). Pada tab performavector (performance)dapat ditampilkan beberapa informasi seperti performance dan description Berikut penjelasan gambar dari masing masing informasi yang ditampilkan oleh RapidMiner. 
Vol. 1 No. 1, Feb 2021, hlm. $111-120$

DOI: https://doi.org/10.33330/.v1i1.1057

Available online at https://jurnal.stmikroyal.ac.id/index.php/jutsi

\begin{tabular}{|l|l|}
\hline $\begin{array}{l}\text { Criterion } \\
\text { Avg. within centroid dis... }\end{array}$ & Davies Bouldin \\
Avg. within centroid dis... & Davies Bouldin: -0.440 \\
Avg. within centroid dis... & Davie \\
\hline Davies Bouldin & \\
\hline
\end{tabular}

Gambar 13. Hasil Davies Bouldin Index (DBI)

Berdasarkan nilai Davies-Bouldin Index (DBI) diatas, menunjukkan bahwa $\mathrm{k}=2$ menjadi klaster terbaik. Nilai DBI $=0.440$ merupakan klastering yang paling optimal dengan nilai DBI minimal.

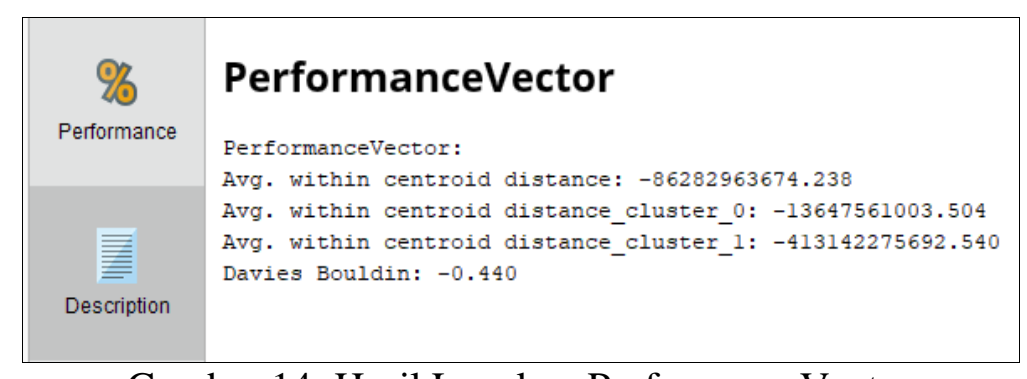

Gambar 14. Hasil Lengkap PerformanceVector

\section{SIMPULAN}

Berdasarkan hasil penelitian dapat disimpulkan bahwa pengelompokan ekspor buah-buahan menurut negara tujuan dapat diterapkan dengan metode $k$-medoids dimana terdapat 2 label klaster yang digunakan yakni klaster tinggi $(\mathrm{C} 1=$ cluster_1) dan klaster rendah $(\mathrm{C} 2=$ cluster_0). Hasil klaster menyebutkan bahwa 2negara berada di klaster tinggi $(\mathrm{C} 1=$ cluster_1 $), 9$ negara berada di klaster rendah $(\mathrm{C} 2=$ cluster_0 $)$. (a) Klaster rendah $(\mathrm{C} 2=$ cluster_0) yakni Amerika Serikat, Thailand, Australia, Pakistan, Peru, Selandia Baru, Vietnam, Afrika Selatan, Mesir., (b) Klastertinggi (C1=luster_1) yakni Tiongkok dan Lainnya.

\section{DAFTAR PUSTAKA}

[1] D. F. Pramesti, Lahan, M. Tanzil Furqon, and C. Dewi, "Implementasi Metode KMedoids Clustering Untuk Pengelompokan Data," J. Pengemb. Teknol. Inf. dan Ilmu Komput., vol. 1, no. 9, pp. 723-732, 2017, doi: 10.1109/EUMC.2008.4751704.

[2] Z. Mustofa and I. S. Suasana, "Algoritma Clustering K-Medoids Pada EGovernment Bidang Information And Communication," J. Teknol. dan Komun., vol. 9, pp. 1-10, 2018. 
Vol. 1 No. 1, Feb 2021, hlm. $111-120$

DOI: https://doi.org/10.33330/.v1i1.1057

Available online at https://jurnal.stmikroyal.ac.id/index.php/jutsi

[3] A. Y. Rofiqi, "Clustering Berita Olahraga Berbahasa Indonesia Menggunakan Metode K-Medoid Bersyarat," J. Simantec, vol. 6, no. 1, pp. 25-32, 2017.

[4] K. Kawano, Y. Umemura, and Y. Kano, "Field Assessment and Inheritance of Cassava Resistance to Superelongation Disease 1 ," Crop Sci., vol. 23, no. 2, pp. 201-205, 1983, doi: 10.2135/cropsci1983.0011183x002300020002x.

[5] W. A. Triyanto, "Algoritma K-Medoids Untuk Penentuan Strategi Pemasaran Produk," Simetris J. Tek. Mesin, Elektro dan Ilmu Komput., vol. 6, no. 1, p. 183, 2015, doi: 10.24176/simet.v6i1.254. 